\title{
ОСОБЛИВОСТІ ФУНКЦІОНУВАННЯ ФРАЗЕОЛОГІЗМІВ УКРАЇНСЬКОЇ МОВИ В ПОЛІТИЧНОМУ ДИСКУРСІ
}

Устатті проаналізовано особливості функціонування фразеологічних одиниць української мови в політичному дискурсі. Розглянуто види структурно-семантичних трансформацій фразеологізмів: еліпсис, субституція, розширення компонентного складу.

Уполітичному дискурсі й узуальні, і трансформовані фразеологізми влучно характеризують актуальні події сьогодення: фінансові питання, співробітництво з партнерами, пересторога про негативні наслідки від неправильних дій тощо.

Ключові слова: політичний дискурс, фразеологічна одиниця, структурно-семантична трансформація.

Kniaz T. M. The Features of Functioning Phraseological Units of the Ukrainian Language in Political Discourse. The political worldview as a part of the national worldview is an open structure that is constantly evolving. The language political worldview is a complex of representations of the people, recorded in the language units about political reality at a certain stage of society development.

The phraseology of the Ukrainian language depends directly on the language political worldview, therefore the phraseological units $(P h U)$ in some way form national and cultural peculiarity of political discourse.

Investigation of the specific features of functioning phraseological units is an effective way to study the representations of the language speakes about political reality, its interpretation, indicating the relevance of the proposed article

The article analyzes the peculiarities of the PhU functioning in the Ukrainian political discourse. The types of structural and semantic transformations of phraseological units are ellipse, substitution, expansion of component composition have been investigated.

In political discourse both traditional and transformed phraseological units accurately characterize current events: financial issues, cooperation with partners, warning about the negative consequences of wrong actions, etc. Diferrent by semantics and structure phraseological units are used in accordance with the linguistic situation, context, author's thought etc. Transformed phraseological unit загравав із проросійським електоратом (the traditional PhU гратися (грати) з вогнем «to behave carelessly, to do something dangerous») is applied to express the author's assessment, the attitude to the political situation.

The function of phraseological units in the political discourse makes it informative and expressive, and thus one of the main functions, influential, is realized. PhUs not only as nominative, but also as estimated units are used with the aim of realization of the unity of rational and emotional information in the text.

Key words: political discourse, phraseological unit (PhU), structural and semantic transformation.

\section{Ветуп}

Поняття «мовна картина світу» належить до фундаментальних, що виражають специфіку людини та ㄲi буття, взаємини іiі зі світом, найважливіші умови існування в ньому. Спостерігаємо підвищений інтерес учених (В. І. Карасик (2000), В. А. Маслова (2008), З. Д. Попова (2007), Л. А. Лисиченко (2009), Й.А. Стернін (2007) та ін.) до різних питань про сфери діяльності людини, що розглядаються як «культурна картина світу», «концептуальна 
картина світу», «релігійна картина світу», «економічна картина світу» тощо. До цих типів картини світу належить i «політична картина світу», що становить систематизовану сукупність вербалізованих знань про політичну діяльність. Мовна політична картина світу, на думку вчених, - це сукупність уявлень народу, зафіксованих у мовних одиницях, про політичну дійсність на певному етапі розвитку суспільства, як інформацію про політичну реальність, відображену в значеннях мовних знаків (Попова \& Стернин, 2007: 54; Декатова, 2018: 70).

Одним з основних методів дослідження в цьому напрямі сучасної лінгвістики є метод дискурс-аналізу, що дає можливість простежити механізми взаємозв'язку між пізнанням, владою і мовою. В. І. Карасик дискурс розуміє як текст, який можна розглядати з різних позицій: соціолінгвістики, прагмалінгвістики, лінгвокультурології, психолінгвістики тощо. Зокрема, з позиції соціолінгвістики вчений виділяє два основні типи дискурсу: інституціональний і персональний. Інституціональний являє собою спілкування в певних рамках статусно-рольових відносин (Карасик, 2000). Відповідно виділяють такі жанри інституціонального дискурсу: політичний, дипломатичний, адміністративний, юридичний, педагогічний тощо.

Науковці розглядають політичний дискурс у вузькому й широкому розумінні. У вузькому контексті - це обмежені політичною сферою жанри. Урядові обговорення, парламентські дебати, партійні програми, виступи політиків - це ті жанри, які належать до сфери політики (Dijk van. T.A. , 1998). Політичний дискурс розуміють винятково як дискурс політиків. У широкому розумінні - це всі форми спілкування, де хоча б один зі складників (суб'єкт, адресат, зміст повідомлення) пов'язаний з політикою. На думку O. I. Шейгал, «будь-який матеріал у ЗМІ, де йдеться про політика й автором якого є політик або, навпаки, адресований політикові, слід зараховувати до кола політичного дискурсу» (Шейгал, 2004: 26). Отже, до сфери політичного дискурсу належать усі матеріали (статті журналістів / політиків, виступи, інтерв'ю, промови), так чи так пов'язані з політичною діяльністю певних осіб чи суспільства.

Оскільки фразеологічний фонд мови безпосередньо залежить від мовної політичної картини світу, фразеологічні одиниці (ФО) певною мірою формують національно-культурну особливість політичного дискурсу. Дослідження специфіки функціонування ФО є ефективним способом вивчення уявлень носіїв мови про політичну дійсність, ії інтерпретацію, що говорить про актуальність пропонованої теми.

Метою наукової розвідки є виявлення специфіки функціонування фразеологізмів української мови в політичному дискурсі та з'ясування можливих змін у структурі й семантиці ФО, що зумовлено прагматичними потребами означеної дискурсивної практики.

\section{Методи та методики дослідження}

У процесі дослідження використовуються описовий метод, фразеологічної ідентифікації, методи функціонального й компонентного аналізу. 


\section{Результати та дискусії}

У політичному дискурсі фразеологізми вважають певними смисловими центрами в мовленні політиків і політологів, які використовують їх з метою зосередження уваги суспільства на певній проблемі чи соціальному явищі. Фразеологічні одиниці завдяки своїй влучності й оригінальності сприяють реалізації одного з основних завдань - прагматичного впливу на адресата.

Політична картина світу як частина національної картини світу є відкритою структурою, що постійно розвивається. Одним зі способів дослідження тенденцій іiї розвитку є аналіз значення фразеологізмів, які активно використовують політичні діячі, журналісти.

Питання статків, фінансового забезпечення представників владних структур завжди жваво обговорюється й журналістами, і політиками, й опозиційними колегами. Саме тому частотним є використання фразеологізмів на позначення багатства, способів заробляння, витрачання коштів: живі гроші; відмивання грошей (коштів); розкидатися грошима; набивати кишені.

Семи 'значний', 'постійний прибуток' актуалізовані в цілісному значенні трансформованої ФО живі гроші (пор.: свіжа (жива) копійка - «хтонебудь має прибуток від чогось») (СФУМ, 2008: 232). Наприклад, Кожен кандидат має залізне право засилати у виборчі комісії своїх представників, яких у потрібний момент може перепродати рейтинговішому кандидатові й отримати за це живі гроші (Український тиждень, 2018).

Різноманітні за семантикою й структурою фразеологічні одиниці застосовують відповідно до мовної ситуації, контексту, авторського задуму тощо. Так, незаконний спосіб заробітку засвідчується семантикою фразеологізму відмивання грошей (коштів): Збереження безвізвого режиму не меншою мірою залежить від того, чи збережеться курс держави у сфері протидії корупиії, відмивання грошей $i$ боротьби з організованою злочинністю; Зокрема, наразі через відхід від демократичних стандартів і системні проблеми у боротьбі з корупиією і відмиванням коштів, $E C$ заморозив низку програм фінансової підтримки Молдови і може відновити їх лише після проведення парламентських виборів (Кальчуцька, 2018). Цікавий факт походження цього фразеологізму, що виник у США у 20-х рр. минулого століття та використовувався офіцерами стосовно пралень, що перебували у власності мафіозних угруповань. Такі незаконні організації демонстрували активну зацікавленість у придбанні пралень, оскільки вони дозволяли легалізувати кошти («відмити» гроші), отримані від кримінальної діяльності (Stessens, 2000). В українському політичному сьогоденні ця ФО є дискурсивно продуктивною з огляду на частотність фактів незаконного поводження з державними грошима.

Заголовок має важливе місце в системі масової комунікації, адже його призначення - бути скомпресованим репрезентантом змісту / головної думки опублікованих матеріалів (Пархонюк, 1999: 323). Можна сказати, що заголовок керує увагою читача, орієнтує його на сприйняття інформації матеріалів. Так, у заголовку «Чому Ахметов почав «розкидатись» грошима та як їх «ловить» Порошенко» використано фразеологізм «розкидатись» грошима, що безпосередньо розкриває зміст статті про фінансові витрати. На нашу думку, «фразеологізми відбивають практичні знання носіїв мови не лише про 
способи отримання грошей (нечесним шляхом, легко / важко заробляти), а й про витрачання грошей: лише маючи значну кількість грошей / зайві гроші, можна легковажно, необдумано їх витрачати» (Князь, 2014: 45).

Про збагачення легким способом, одержання прибутку сигналізує фразеологізм набивати кишені у складі заголовку в інтернет-виданні «Politeka» «Набивали кишені, торгуючи з агресором: українці в люті від иинічної заяви Гройсмана» (Сайт Politeka, 2018).

Як відомо, автори статей не лише констатують факти, але й висвітлюють певні події крізь призму суб'єктивного світосприйняття, що нерідко використовується як засіб впливу на певну категорію суспільства. Про необхідність працювати в інтересах різних сторін, підтримувати одночасно дві протилежні сторони свідчать ФО вести подвійну гру; сісти на два стільці: Тим, хто сформує украӥнську владу протягом 2019 року, доведеться вести подвійну гру; Проукраӥнські кандидати прагнутимуть якщо не сісти на два стільці, то хоча б не відлякати тих, хто бажає не так реформ, як посилення державної опіки (Віхров, 2018).

Цікавим є функціонування ФО у назвах статей, де фразеологізми виконують номінативну функцію, акцентуючи увагу на актуальних і важливих проблемах. Наприклад, назва: «Сидіти на двох стільиях неможливо: ексnерт викрив Тимошенко, вказавши на ї̈ некомпетентність» (Сидіти, 2018). Специфіка ФО сидіти на двох стільцях не обмежується лише номінативною функцією, авторська інтенція - зорієнтувати читача на те, що далі йтиметься про неправильну стратегію роботи штабу Тимошенко. Із ширшого контексту зрозуміло, що політолог Кирило Сазонов говорить про те, що не можна пані Тимошенко обіцяти населенню низькі тарифи, а потім на форумі YES брехати про ринок цін.

3 метою підкреслення незалежності країни, можливості самостійно впоратися з військовими питаннями М. Саакашвілі в інтерв’ю газеті «Кореспондент» використав ФО стояти на своїх двох (трансформований варіант узуальної ФО твердо (міцно) стояти на ногах (на землі) - «упевнено діяти, мислити і т. ін.» (СФУМ, 2008: 531). У нас (у Грузії) теж була військова ситуація, ми відмовилися. Країна повинна стояти на своїх двох, а не рухатися на милииях (Саакашвілі, 2016).

Про небезпеку, застереження виконання певних дій, що можуть мати різні наслідки, зокрема й негативні, свідчать як узуальні, так і трансформовані фразеологізми: поставити під удар; загравати із проросійським електоратом; висітиме, як дамоклів меч. Наприклад: $Е$ одна відома особа, яка досі живе в Криму і була готова нам давати свідчення попри все - але нас попросили не брати їх, бо це поставить ї̈ під удар (Сидоренко, 2018).

Спостерігаємо використання таких видів трансформацій, як субституція й розширення компонентного складу: загравав із проросійським електоратом (пор.: гратися (грати) з вогнем - «поводитися необережно, здійснювати що-небудь небезпечне») (СФУМ, 2008: 119). При цьому атрибутивний компонент проросійським безпосередньо вказує на суб'єкт, з яким були певні дружні / ділові стосунки, що можуть мати різні наслідки. Наприклад: У 1994 році вибориі останнього вже підтримали Кравчука проти Кучми, 
оскільки той загравав із проросійським електоратом (Віхров, 2018). Трансформований фразеологізм застосовано для висловлення авторської оцінки, ставлення до політичної ситуації.

3 метою підкреслення надзвичайної небезпеки Іван Ліщина (заступник Міністра юстиції) в інтерв’ю газеті «Європейська правда» використовує фразеологізм висітиме, як дамоклів меч: У нинішній політичній ситуаціїнапевно, так. Але навіть якщо вони [росіяни] вийдуть з Ради Європи - це не зніме питання щодо невиконання. Це рішення висітиме над ними, як дамоклів меч (Сидоренко, 2018). Цей вислів має міфологічне походження: за давньогрецьким переказом, Діонісій запропонував на один день посісти свій престол Дамоклу, який вважав його найщасливішою людиною у світі, яка має все. Однак під час бенкету Дамокл побачив над своєю головою гострий меч, що висів на кінській волосині. Так Діонісій показав Дамоклу, що добробут це лише примара.

Для перестороги виникнення небезпечної політичної ситуації для України, зокрема можливості призупинення безвізового режиму Єврокомісією, використано фразеологізм відкрити скриньку Пандори: Але Україна - завелика держава, і загальні європейські правила не завжди повторюються із нами. Отже, не варто бути впевненими, що ігнорування вимог $С С$ не відкриє для нас скриньку Пандори (Сидоренко, 2018). Спостерігаємо розширення компонентного складу узуальної ФО скриня Пандори - «вмістилище зла» (СФУМ, 2008: 500), відповідно в контексті фразеологізм реалізує дещо інше значення «виникнення складної ситуації». Як відомо, у грецькій міфології Пандора перша жінка, створена богом вогню. Бог Зевс подарував їй скриньку, у якій були людські нещастя. Через цікавість Пандора відкрила скриньку, з неї вилетіло все лихо й поширилося скрізь. На дні скриньки залишилася лише надія. Отже, зрозуміло, чому скринька Пандори - джерело проблем, нещасть.

Вочевидь, у політичному дискурсі функціонують фразеологізми, що містять культурологічну інформацію міфологічного характеру, особливо ФО, до складу яких належать власні назви, які орієнтують на певну історичну подію. При цьому зауважимо, що фразеологізми за своєю етимологією, значенням досить неоднорідні, що змушує автора статті, журналіста, політолога, політика з обережністю їх використовувати, заздалегідь прогнозуючи готовність сприйняття матеріалу, який містить подібні одиниці, адже не кожна людина на достатньому рівні володіє фразеологічним фондом української мови для адекватного розуміння змісту повідомлення.

\section{Висновки}

Отже, у політичному дискурсі функціонують як узуальні, так і трансформовані фразеологізми, що влучно характеризують актуальні події сьогодення: фінансові питання, співробітництво з партнерами, пересторога про негативні наслідки від неправильних дій тощо. Різноманітні за семантикою й структурою фразеологічні одиниці застосовують відповідно до мовної ситуації, контексту, авторського задуму тощо.

Функціонування фразеологічних одиниць у політичному дискурсі робить його інформативним й експресивним, завдяки чому реалізується одна з основних функцій - впливова. Фразеологізми мають як номінативну, так 
й оцінну функції, тому використовуються з метою реалізації в тексті єдності раціональної й емоційної інформації.

Проте цим не вичерпується аналіз пропонованої теми, тому напрям подальших розвідок полягатиме в здійсненні комплексного аналізу фразеологічного матеріалу в політичному дискурсі з позицій прагмалінгвістики та когнітивної лінгвістики.

\section{ЛІТЕРАТУРА}

1. Декатова К. И. Фразеологическое значение как средство изучения политической картины мира. Жизнь фразеологии - фразеология в жизни : сб. науч. ст. Кострома , 2018. С. 70-77. 2. Карасик В. И. О типах дискурса. Языковая личность: институциональный и персональный дискурс. Волгоград, 2000. С. 5-20. 3. Князь Т. М. Фразеологізми української мови на позначення заможності: структурно-семантичний, ідеографічний, лінгвокультурологічний аспекти: монограф. Харків: Точка, 2014. 176 с. 4. Лисиченко Л. А. Лексико-семантичний вимір мовної картини світу : монограф. Харків : Основа, 2009. 191 с. 5. Маслова В. А. Политический дискурс: языковые игры или игры в слова? Политическая лингвистика. Екатеринбург, 2008. Вып. 1(24). С. 43-48. 6. Попова 3. Д., Стернин И. А. Когнитивная лингвистика: монограф. Москва: АСТ: Восток-Запад, 2007. 314 с. 7. Пархонюк Л. Синтаксичні засоби актуалізації у газетних заголовках. Українська філологія: Школи, постаті, проблеми. Львів: Світ, 1999. Ч. 2. С. 323 - 326. 8. СФУМ Словник фразеологізмів української мови / [укл. В. М. Білоноженко, І. С. Гнатюк, В. В. Дятчук та ін.]. Київ: Наук. думка, 2008. 1104 с. 9. Шейгал Е. И. Семиотика политического дискурса. Москва: Гнозис, 2004. 326 c. 10. Dijk van.T.A. What is Political Discourse Analysis. Amsterdam, 1998. URL: http:// www.discourse-in-society.org. 11. Stessens G. Money Laundering: a new international law enforcement model. Cambridge University Press., 2000. 460 p.

\section{ПУБЛІЦИСТИЧНІ ДЖЕРЕЛА}

12. Віхров М. Вибори і пастки популізму [Електронний ресурс] // Український тиждень. 2018. URL: https://tyzhden.ua/Politics/223832. 13. Кульчицька К. За що не заберуть безвіз: деталі звіту ЄС про Україну, Грузію та Молдову [Електронний ресурс] // Європейська правда. 2018. URL: https://www.eurointegration.com.ua/ articles/2018/12/21/7090937/. 14. Сайт Politeka [Електронний ресурс]. 2018. URL: https://politeka.net/ua/news/617231-nabivali-karmany-torguya-s-agressorom-ukraintsy-vyarosti-ot-tsinichnogo-zayavleniya-grojsmana/ 15. Саакашвілі привів у приклад Грузію, яка «дуже швидко» відмовилася від допомоги МВФ [Електронний ресурс] // Корреспондент.net. URL: https://ua.korrespondent.net/ukraine/politics/3738522-saakashvilipro-transh-mvf-my-znovu-zimo-tsi-hroshi. 16. Сидоренко С. Залишаємо земельний мораторій? [інтерв'ю] // Європейська правда. 2018. - URL: https://www.eurointegration. com.ua /interview/2018/12/19/7090810/ 17. Сидіти на двох стільцях неможливо: експерт викрив Тимошенко, вказавши на iї некомпетентність [Електронний ресурс] // Politeka. 2018. URL: https://politeka.net/ua/news/ politics/733948-sidet-na-dvuhstuljah-nevozmozhno-jekspert-razoblachil-timoshenko-ukazav-na-ee-nekompetentnost/ 18. Український тиждень: сусп.-політ. журнал. [Електронний ресурс] 2018. №40 (568). URL: https://tyzhden.ua/Politics/220658

\section{REFERENCES}

1. Dekatova, K.I. (2018) Frazeolohicheskoie znacheniye kak sredstvo izucheniia politicheskoi kartiny mira [Phraseological value as a means of studying the political worldview]. Zhizn frazeolohii - frazeolohiia v zhizni. - Life phraseology - phraseology in life. Kostroma, (pp. 70-77) [in Russian]. 2. Karasik, V.I. (2000) O tipakh discursa [About discourse types]. Yazykovaya lichnost: institutsionalnyi i personalnyi diskurs. - Language personality: institutional and personal discourse. Volgograd, (pp. 5-20) [in Russian]. 3. Kniaz, T.M. (2014) Frazeolohizmy ukrayinskoi movy na poznachennia zamozhnosti: strukturno-semantychnyi, 
ideohrafichnyi, linhvokulturologichnyi aspekty [Phraseological units of the Ukrainian language which denote the prosperity state: structural and semantic, ideographic, linguo-cultural aspects]. Kharkiv: Tochka, 176 [in Ukrainian]. 4. Lisichenko, L. A. (2009) Leksyko-semantychnyi vymir movnoyi kartyny svitu [Lexical and semantic dimension of language of the worldview]. Kharkiv: Osnova, 191 [in Ukrainian]. 5. Maslova, V.A. (2008) Politicheskii diskurs: yazykovyie igry ili igry v slova [Political discourse: language games or word games?] Politicheskaia lingvistika - Political linguistic, issue 1(24) (pp. 43-48). Yekatierinburg [in Russian]. 6. Popova, Z.D. \& Sternin, I.A. (2007) Kognitivnaia lingvistika /Cognitive linguistics]. Moskva: AST: Vostok-Zapad, 314 [in Russian]. 7. Parkhonyuk, L. (1999) Syntaksychni zasoby aktualizatsiyi $\mathrm{u}$ hazetnykh zaholovkakh [Syntactic means of updating in newspaper headings]. Ukrayinska filolohiya: Shkoly, postati, problemy - Ukrainian philology: Schools, figures, problems, issue 2 (pp. 323-326). Lviv: Svit [in Ukrainian]. 8. Sheygal, Ye. I. (2014) Semiotika politicheskoho diskursa [Semiotics of political discourse]. Moskva: Gnozis, 326 [in Russian]. 9. Bilonozhenko, V. M., Hnatiuk, I. S., Dyatchuk, V. V. (2008) Slovnyk frazeolohizmiv ukrainskoi movy [Dictionary of phraseology of the Ukrainian language]. Kyiv: Naukova dumka [in Ukrainian]. 10. Dijk van.T.A. What is Political Discourse Analysis. Amsterdam, 1998. Retrieved from http://www.discourse-in-society.org. 11. Stessens G. Money Laundering: a new international law enforcement model. Cambridge University Press., 2000. 460 p.

\section{PUBLITSYSTYCHNI DZHERELA - JOURNALISTIC SOURCES}

12. Vikhrov, M. (2018) Vybory i pastky populizmu [Selections and traps of populism]. Ukrainskyi tyzhden - Ukrainian Week. Retrieved from https://tyzhden.ua/Politics/223832. 13. Kulchytska, K. (2018) Za shcho ne zaberut bezviz: detali zvitu YES pro Ukrainu, Hruziiu ta Moldovu [For which will not be taken away without a visa: details of the EU report on Ukraine, Georgia and Moldova]. Yevropeiska pravda - European truth. (n.d.). eurointegration. com.ua Retrieved from https://www.eurointegration.com.ua/articles/2018/12/21/7090937/ 14. Sait Politeka [Site Politics]. (2018) (n.d.). politeka.net/ua. Retrieved from https://politeka.net/ua/news/617231-nabivali-karmany-torguya-s-agressorom-ukraintsy -v-yarostiot-tsinichnogo-zayavleniya-grojsmana/ 15. Sydorenko, S. (2018) Zalyshayemo zemelnyi moratorii? [Leave land moratorium?]. Yevropeiska pravda - European truth. Retrieved from https://www.eurointegration.com.ua /interview/2018/12/19/7090810/ 16. Saakashvili pryviv u pryklad Hruziiu, yaka «duzhe shvydko» vidmovylasia vid dopomohy MVF [Saakashvili cites Georgia as an example, which «very quickly» refused to help IMF] (2016). Korrespondent.net. - Correspondent.net. Retrieved from https://ua.korrespondent.net/ukraine/ politics /3738522-saakashvili-pro-transh-mvf-my-znovu-zimo-tsi-hroshi 17. Sydity na dvokh stiltsyakh nemozhlyvo: ekspert vykryv Tymoshenko, vkazavshy na yii nekompetentnist [It is impossible to sit on two chairs: the expert exposed Tymoshenko, pointing out her incompetence]. (2018). Politeka - Politics. (n.d.). politeka.net/ua. Retrieved from https:// politeka.net/ua/news/politics/733948-sidet-na-dvuh-stuljah-nevozmozhno-jekspertrazoblachil-timoshenko-ukazav-na-ee-nekompetentnost/ 18. Ukrainskyi tyzhden [Site of journal «Ukrainian Week»]. (n.d.). https://tyzhden.ua. Retrieved from https://tyzhden.ua/ Politics/223832

Князь Тетяна Миколаївна - кандидат філологічних наук, доцент, доцент кафедри мовних дисциплін, Харківський національний аграрний університет імені В. В. Докучаєва; с. Докучаєвське, Харківський р-н, Харківська обл., 62483, Україна.

Tel.: +380677890433

E-mail knyaz_tm@ukr.net

http://orcid.org/0000-0002-7272-4644

Kniaz Tetiana Mykolaivna - PhD in Philology, Associate Professor, Department of linguistic disciplines, V. V. Dokuchaev Kharkiv National Agrarian University; Dokuchaievske vil., Kharkiv region, 62483, Ukraine. 